Premise : Journal of English Education and Applied Linguistics

PP)IEIE

https://fkip.ummetro.ac.id/journal/index.php/english

Aryani

\title{
DEVELOPING SCREAMBLE MEDIA TO ENHANCE SPEAKING SKILL FOR PRESCHOOLERS
}

\author{
by \\ Rosita Aryani \\ Cahaya Bangsa School Metro, Lampung Indonesia \\ rositaaryanistain@gmail.com
}

Received: April 24, 2019

Resent: July 3, 2019

Reviewed2: August 2, 2019

Accepted: September 30, 2019
Reviewed1: July 2, 2019

Revised: August 25, 2019

Reviewed3: August 27, 2019

Published: October 19, 2019

\begin{abstract}
:
This study aims to develop SCREAMBLE media to enhance speaking skill among preschoolers in Cahaya Bangsa School Metro. A research question is formulated: is SCREAMBLE media effective to enhance speaking skill? The participants are 18 preschoolers of Kindergarten B chosen by purposive cluster sampling. This is a kind of educational research and development designed by certain procedures; setting the instructional goals, procedures, and materials, conducting performance objectives, field-testing, assessing instruments, doing formulative and summative evaluation. The result gathered by Wilcoxon test represents Asymp.Sig (2-tailed) values 0,000 which is smaller than 0,05 indicates that SCREAMBLE media is effective to enhance speaking skill. Besides, observation reveals that preschoolers are excited to speak since their fine motor and cognitive aspects are included simultaneously.
\end{abstract}

Keywords: SCREAMBLE, speaking, preschoolers

\section{INTRODUCTION}

Prior study in Research and Development (R\&D) to improve the students' speaking in area of English as Foreign Language (EFL) focused on several different skills. Some researchers proposed to develop discovery learning-based assessment module to stimulate critical 
thinking and creativity of students' speaking performance (Wahyudi, Rukmini\&Bharati, 2019). This previous study provoked the needs of media to insist speaking performance by constructing a module.

Another research was the development of English language learning instruments using audio-based media for middle schools (Adi, 2016). Findings of the research reveal that audio - based media allowed middle school to imitate the audio together which could facilitate the achievement of a learning goal, that was to speak with acceptable pronunciation, stresses and intonation. Particular English module was also intoduced for hospitality students using inquiry-based language learning (Milaningrum, 2019). Similar to R and D in the area of essay writing was also reported by Turmudi \& Baihaqi (2019) despite in the stage of need analysis.

Findings visualized that inquiry based language learning led to the appropriate module which met to students' need specific to their major. In line with the former study, developing material for communicative language teaching (CLT) was done to teach English for economics students (Qomar, 2017). This research generated CLT Book Material as a media to learn and do English grammar, specifically in part of speech. To support improvement for speaking skill, one English learning material was developed based on problem - based learning (PBL) attempted to propose descriptive and recount text for speaking materials (Fajarwati, 2014).

Some steps of developing materials according to Common European Frameork of Reference (CEFR) was introduced to increase speaking skill generated eleven units in the handout, those are speaking materials, writing activities, spoken activities, notes and let's make a summary. (Yuniarti, 2017). The last kind of media was authentic short movies used to enhance speaking skill intended for senior high school students (Madiyoh, 2018). This teaching aid emphasized to exchange traditional method with something new, that was short movie to give a brief overview before the students speak.

That is why I am interested in developing SCREAMBLE media to enhance speaking skill. However, the focus of this study is the development of SCREAMBLE media for for preschoolers. Due to many areas in $\mathrm{R}$ and $\mathrm{D}$ that are left out to study, the researcher has decided to focus on developing the SCREAMBLE media to enhance speaking skill for 
preschoolers by the following reasons:

1. Preschoolers acquire their language through listening first

2. Preschoolers are quite interested in activity involving psychomotor aspect

3. The media is used as the alternative source of language input

4. The media is so flexible to teach simple grammar

5. This media enables preschoolers to comprehend both sounds and letters which construct a word

Thus the objectives of this research are:

1. To empower preschoolers' acquisition of foreign language

2. To enlarge a new kinds of media which is fit to underage children

3. To find out another language source except teachers

4. To build an underlying concept about simple grammar

5. To encourage preschoolers' passion and bravery to speak

The researcher believes that this study will contribute to the field of knowledge in area of speaking for preschoolers as stated in the following conditions:

1. As a reference for the other ELT to adapt and adopt this media in any subject matter

2. As a renewal for Foreign Language Teaching for Early Childhood Education

3. As a predisposition that teaching speaking for Early Childhood Education is quite easy and pleased

Upon all, however, it is worth explaining how this study is important theoretically. As known, speaking is one of language proficiency that verbalizes human notions and ideas. It is two-way propositions including particular phases of producing, receiving and processing information (Mede, 2017). Speaking skill, notably, in Indonesia, desires certain media or teaching aids to ease the acquisition process. Since speaking is an interactive process of constructing meaning which includes producing and receiving discourse to process information (Burns, 2012). Implicitly, the ways to develop speaking skill are considered as repeating utterances, improving belonging utterances and bringing together two kinds of utterances, one of his own's and one of the other's. Some aspects to belong speaking skill involve pronunciation, fluency, vocabulary and accuracy (Brown, 2007). Pronunciation has a 
great deal with phonology in which it directs on how people pronounce words or morphemes relying on the contexts (Fromkin, Rodman\&Hyams, 2017).

To be known, pronunciation refers to the way of uttering producted sounds in which it results resolute speaking. Meanwhile, fluency depends on how deep human acquire language to realize it in spoken version whereby acquisition is in charge of better fluency. As proposed, children acquire two or more languages during critical period simultaneously (Gass\&Selinker, 2008). What should be appraised is that acquisition underlies fluency since it is a restrained growth of language aptitude which takes place by nature to whom the meaningful communication posses (Yule, 2010).

Further, a language's vocabulary works in progress and the profound obligation is just to find the ways to create words as result of giving new meaning of a language as well as giving new form (O’Grady, 2005). Barriers of accuracy comes from grammatical constructions for it plays a huge role to identify different situation in which speaking takes place (Harmer, 2007). Besides, under normal circumstances, a child undergoes a biological basis of language acquisition known as critical period hypothesis is coming from birth to puberty (Fromkin, Rodman\&Hyams, 2017). During this period, human brain is in the phase of readiness to receive input of acquisition that ease him to obtain language flawlessly.

On the other hand, successive bilinguals take place in the age of 3 to 7 whereas late successive bilinguals occur in the age after 7 but before puberty (Fromkin, Rodman\&Hyams, 2017). These facts indicate that the building blocks of teaching speaking are best in the phase of pre-school. Some scholars affirmed the three behaviors of speaking development as babbling, unintelligible imitation and preliminary stage (Ingram, 1997). Schmidt, in his study towards a young Japanese artist who learned English in Honolulu, defined a pursuit of English acquisition of the Japanese as something odd by predisposition 'I am never learning, I am only just listen then talk.

The illustration above is excerpted as 'the Japanese always listened as much as possible, thought what utterances he heard then started to talk' with the frequency of $75 \%$ $90 \%$ of a time (Ortega, 2013). Whereas the existence of oral interaction from native or nearnative speakers whose sufficient proficency may lead to an authentic input (Krashen, 2009). 
In order to define speaking acquisition, by getting aside the presence of cognition, aptitude and motivation, the underlined mechanism of that term represent as imitation, reinforcement, analogy and structured input (Fletcher\&Garman, 1986). So complicated does the process of acquisition to trigger of speaking skill that the researcher found in Kindergarten B of Cahaya Bangsa School whereby most of the preschoolers were difficult to speak fluently since they did not comprehend the sounds and letters of a word.

Some of them just memorized the pronunciation of morphemes without being able to determine letters of the sounds belong. As we understand that memorizing leads to learning whereas comprehending leads to acquiring instead. The dawn of learning media becomes something significouldt since pre-schoolers acquire information much through learning by doing. On the contrary, media to enhance speaking skill is not served enough in which most of them couldnot take psychomotor and cognitive into account at the same time. Due to the fact above, the researcher desires to construct a media to enhance speaking skill among preschoolers by conducting study and development to create a new media and examined by pre-experimental design.

Concern to acquisition which leads to speaking skill, learning media accomodates the barriers existed. The use of media to reinforce language acquisition is such a prominent matter. Through this study, the researcher develops one new media to enhance speaking skill named SCREAMBLE. SCREAMBLE is a non-machine media to enhance English speaking skill which clustered as audio-visual media. SCREAMBLE comes from two components of magic house and SCREAMBLE board. Magic house attractively functions to display flashcards in order to be spelled and memorized by preschoolers. Continued to SCREAMBLE board as a place to re-arrange words appeared in the magic house.

Through magic house, preschoolers could maximize their auditory and sight systems to catch the sounds pronounced by themselves whereas SCREAMBLE board practices their psychomotor, cognitive, memory and accuracy aspects in choosing the match letters. SCREAMBLE is so flexible that it gives a broad opportunity to preschoolers to determine the way of words either turning right or getting down. Practical value of SCREAMBLE is it could be applied for all subjects of fields even in the frame of structure and grammar. Magic house 
is made of recycled carton shaping to be a manipulated house consists of one small hole to pop the flashcards whereas SCREAMBLE board is constructed by board full of squares in which the provided letters are made of recylced bottle.

The procedures of using this media are; the teachers serve several flashcards based on the theme without being known by preschoolers. The teachers diplays the flashcards one by one in magic house accompanied by certain stimulus question just like 'oh, what picture will appear after this?', then the teachers pull the flashcards until picture and letters appear. Preschoolers then spell and memorized the letters several times. Next, they move to SCREAMBLE board where the teachers stimulate children by simple statment of ' $I$ have two eggs.' What surprised is that preschoolers will soon look for letters of 2, egg, and $s$ to arrange them on the board.

They have right to determine the starting line directed to turning right or getting down. The teachers have to ensure the lines of letters still have relation each other. After finishing all the words, the teachers asked questions of 'What have you found? What food is this? How many?' and so on. Without being conscious, the preschoolers have already learnt simple grammar of '-s ending for plural things'. Regarding to explanation above, the researcher wants to know the development of SCREAMBLE media, the students' behaviors and attiudes towards the use of SCREAMBLE media within teaching-learning process and the influence of SCREAMBLE media to magnify speaking skill.

In line with the theories above, some problems are identified; the need of convenient media to enhance speaking skill, English input comes from the teachers solely, the lack of vocabulary and pronunciation comprehension.

Upon all, the research questions of the study are:

1. What makes preschoolers difficult to speak fluently?

2. What is an effective media which engages to speaking skill?

3. Is there any other language input instead of teachers as facilitators?

Premise Journal Vol. 8 No 2, October 2019, e-ISSN: 2442-482x, p-ISSN: 2089-3345, p.144-162 Copyright@2019 by PJEE 


\section{METHODS}

\section{Design}

Design of this study was Educational Research and Development in which a new product was designed and developed orderly through certain steps of field-testing, evaluating and refining to attain the standard of compatibility (Gall \& Borg, 2003).

\section{Procedures of Developing SCREAMBLE Media}

The procedures of development were taken under 10 following steps (Dick \& Carey, 2003):

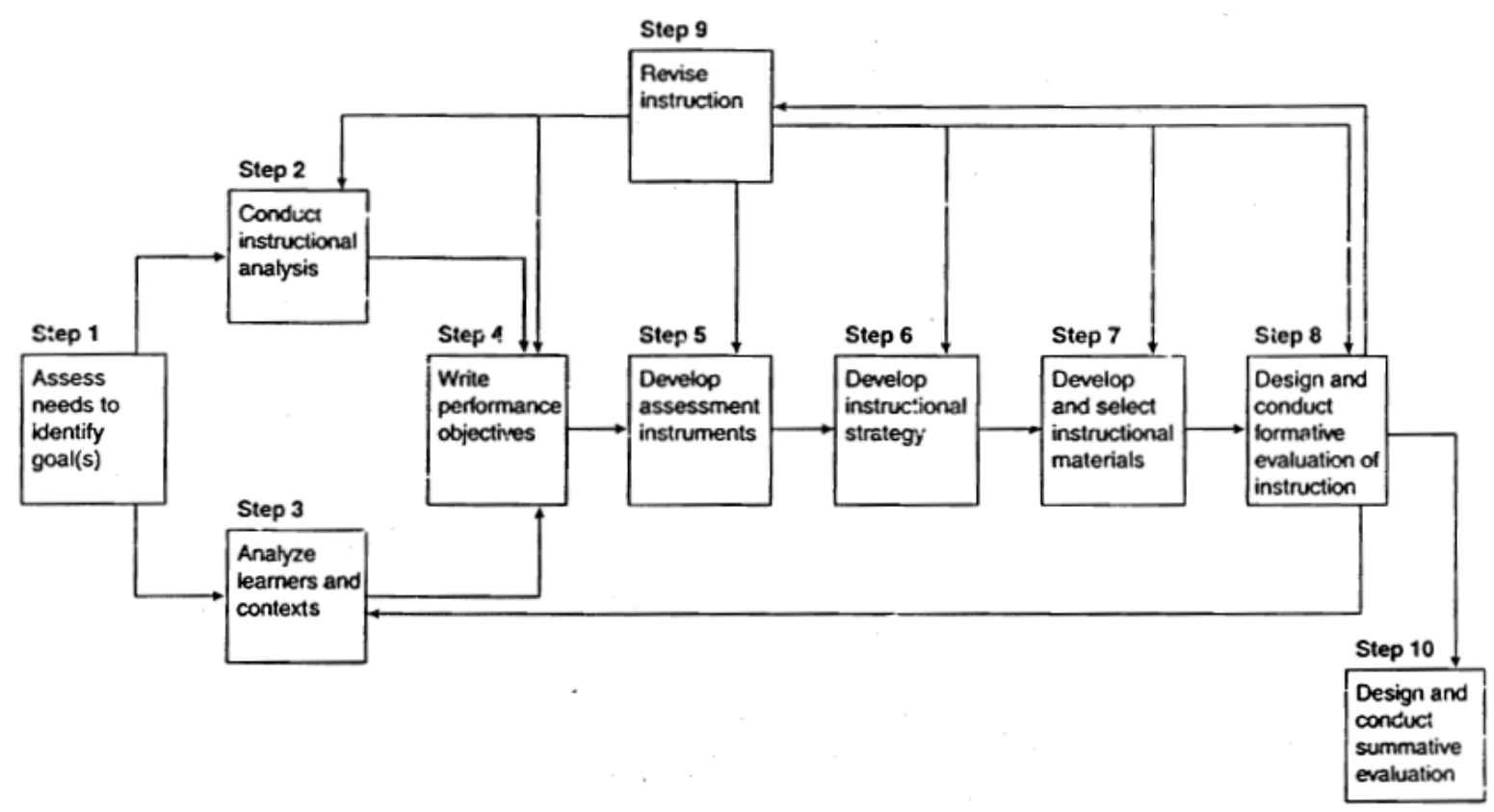

Figure 1: Diagram by Dick \& Carey, 2003.

Procedures of developing SCREAMBLE media adapted by 10 steps above were considered as (1) analyze the preschoolers' needs to enhance speaking skill at least in one word or simple phrase; (2) conduct specific procedures and learning tasks to reach the goal, in this case, spelling, memorizing sounds and rearranging letters (3) review the literature of 
preschoolers' phases of acquisition by age, cognition, social, and psychological factors; (4) turn the instructional analysis into specific model of media, magic house and SCREAMBLE board; (5) develop verbal test to assess the effectiveness of model; (6) conduct a strategy to use the media; (7) develop materials to use the media, those are "my parts of the body", "transportations" and "healthy \& unhealthy foods and drinks"; (8) conduct a formative evaluation through observation and scoring rubric; (9) revise the media and (10) conduct a summative evaluation through external examination by pre-experimental design.

\section{Participants}

Subject of this study was 18 preschoolers at Kindergarten B in Cahaya Bangsa School. They were 9 male and 9 female students. The validator of expert judgement for this media was an English lecturer from IAIN Metro, Mrs. Diah Maulidya Hans, M.Pd.

\section{Instrument and Data Type}

The instrument of this study was verbal test in which the preschoolers were provided by some verbal questions about parts of the body, healthy/unhealthy foods and drinks, and transportations. The rating scale of scoring rubric was used to measure the instrument. Whereas the type of data was quantitative data gathered by scoring rubric that led to external examination designed by pre-experimental design of one group pre-test post-test.

Table 1: Indicators of Speaking Skill

\begin{tabular}{|c|c|c|c|}
\hline \multirow{2}{*}{ Criteria } & \multicolumn{3}{|c|}{ Aspects } \\
\hline & Pronunciation & Vocabulary & Grammar \\
\hline 4 (BSB) & $\begin{array}{l}\text { Pronunciation is } \\
\text { excellent; good } \\
\text { effort of accent }\end{array}$ & $\begin{array}{l}\text { Excellent control of } \\
\text { language features; a } \\
\text { wide range of well- } \\
\text { choosen vocabulary }\end{array}$ & $\begin{array}{l}\text { Accuracy } \\
\text { grammatical } \\
\text { structures }\end{array}$ \\
\hline $3(\mathrm{BSH})$ & $\begin{array}{l}\text { Pronunciation is } \\
\text { good; good effort } \\
\text { of accent }\end{array}$ & $\begin{array}{l}\text { Good control of } \\
\text { language features; a } \\
\text { good range of } \\
\text { relatively } \\
\text { choosen vocabulary }\end{array}$ & $\begin{array}{l}\text { Some errors in } \\
\text { grammatical } \\
\text { structures }\end{array}$ \\
\hline $2(\mathrm{MB})$ & $\begin{array}{l}\text { Pronunciation is } \\
\text { fair; some effort } \\
\text { of accent, but is }\end{array}$ & $\begin{array}{l}\text { Adequate language } \\
\text { control; vocabulary } \\
\text { range is sufficient }\end{array}$ & $\begin{array}{l}\text { Frequent } \\
\text { grammatical errors }\end{array}$ \\
\hline
\end{tabular}

Premise Journal Vol. 8 No 2, October 2019, e-ISSN: 2442-482x, p-ISSN: 2089-3345, p.144-162 Copyright@2019 by PJEE 


\begin{tabular}{|c|l|l|l|}
\hline & $\begin{array}{l}\text { definitely non- } \\
\text { native }\end{array}$ & \\
\hline \multirow{3}{*}{$1(\mathrm{BB})$} & $\begin{array}{l}\text { Pronunciation is } \\
\text { poor; no effort } \\
\text { towards a native } \\
\text { accent }\end{array}$ & $\begin{array}{l}\text { Weak language } \\
\text { control; vocabulary } \\
\text { choice is poor }\end{array}$ & $\begin{array}{l}\text { Much grammatical } \\
\text { errors }\end{array}$ \\
\hline
\end{tabular}

Source: Permendikbud 137 in 2014 (modified with speaking scoring rubric)

\section{Data Collecting Technique}

In this study, the reseacher used documentation to perpetuate preschoolers' conditions. The researcher used observation and verbal test as well. Verbal test consists of pre-test and post-test which had been modified appropriately to preschoolers' age development. Pretest led to simple verbal question of 'how to say dua puluh?' whereas post test managed to 'i like eating two apples in a day. What are the letters? What is your favorite foods?'. Observation is done to analyze the children behaviors during the usage of this media within teahing-learning process. In order to measure preschoolers' attitude during the use of SCREAMBLE media, the researcher accomodates particular indicators as follows; (1) pay attention to the teacher's explanation, (2) say the name of entities appearing in the magic house, (3) spell the letters several times, (4) find the letters correctly, (5) arrange the letters in the SCREAMBLE board, (6) insert 'grammar function of -s ending' in the letters to indicate quantity, (7) help friends to find the letters and (8) help friends to arrange the letters.

\section{Data Analysis Technique}

Technique to analyze the effectivity of $S C R E A M B L E$ media in this study was using Wilcoxon test.

\section{RESULT AND DISCUSSION}

\section{Result}

The findings of this study was represented by the following diagrams:

Diagram 1: Histogram of pretest result

Premise Journal Vol. 8 No 2, October 2019, e-ISSN: 2442-482x, p-ISSN: 2089-3345, p.144-162

Copyright@2019 by PJEE 


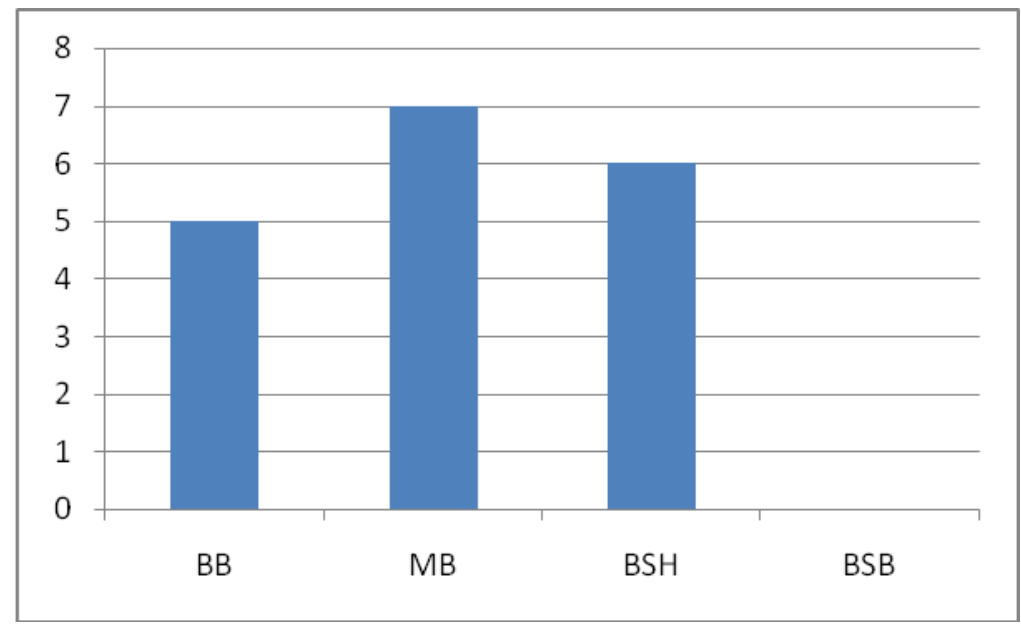

Diagram above symbolized that 5 preschoolers got BB (Belum Berkembang) score, 7 preschoolers were in the level of MB (Masih Berkembang) score, then 6 preschoolers were crossing to BSH (Berkembang Sesuai Harapan) but no one engaged to BSB (Berkembang Sangat Baik) score.

Diagram 2: Histogram of Posttest result

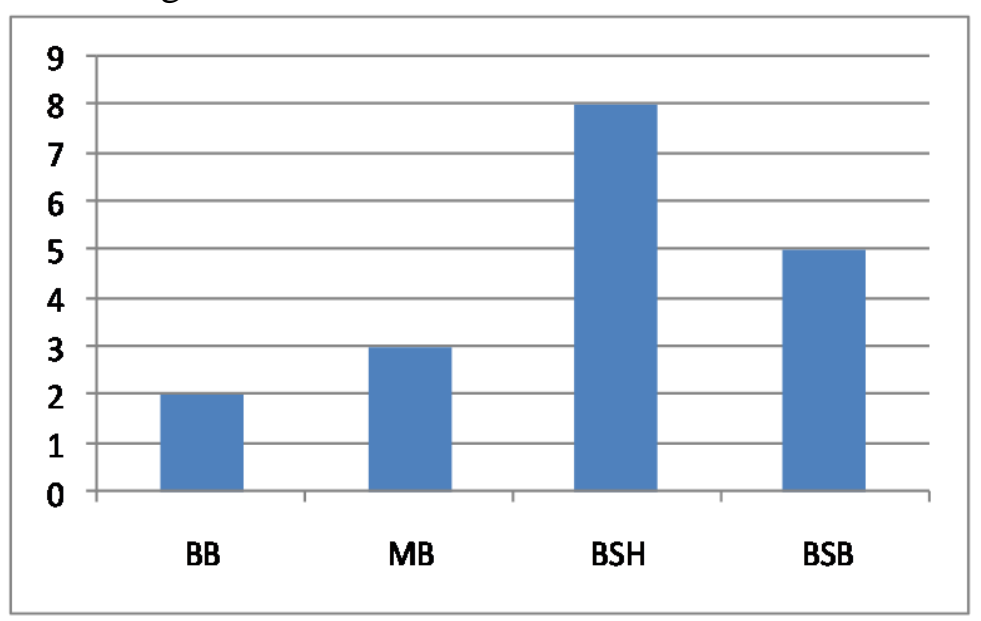

This diagram visualized that there was refinement in preschoolers' score on posttest result. For about 2 students got BB (Belum Berkembang) score, whereas 3 preschoolers were in MB (Masih Berkembang) score. Next, 8 preshoolers moved to BSH (Berkembang Sangat Baik) score and the last, 5 students were better in BSB (Berkembang Sangat Baik) score. 
Table 2: Observed activity during the use of SCREAMBLE media

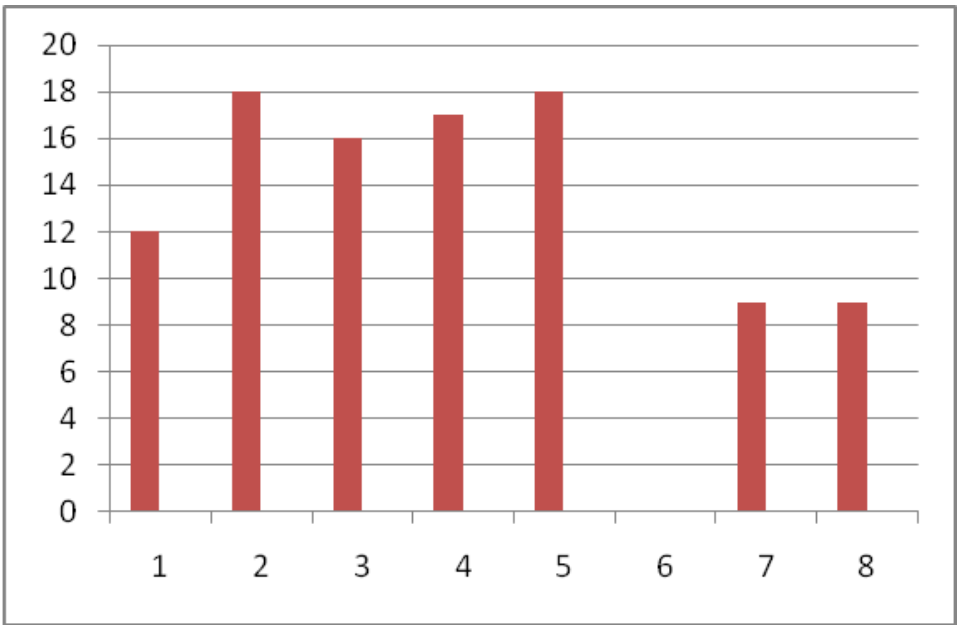

Indicators:

1. Pay attention to the teacher's explanation

2. Say the name of entities appearing in the 'magic house'

3. Spell the letters several times

4. Find the letters correctly

5. Arrange the letters in the SCREAMBLE board

6. Insert 'grammar function of - s ending' in the letters to indicate quantity

7. Help friends to find the letters

8. Help friends to arrange the letters

Table 3: Observed activity during the use of SCREAMBLE media

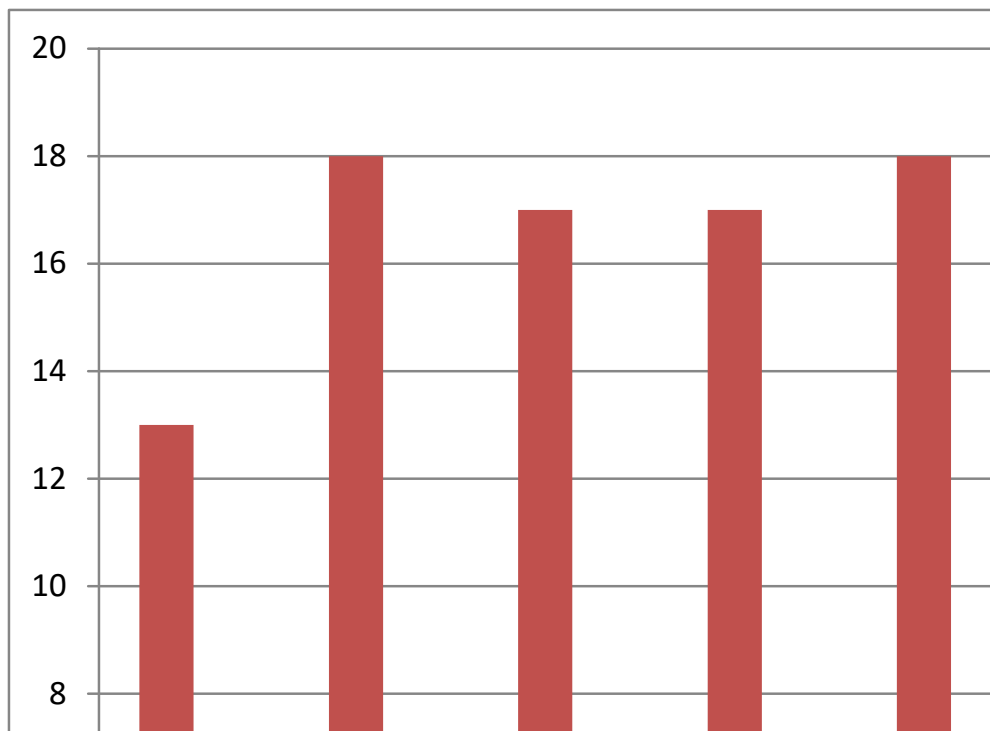

Premise Journal Vol. 8 No 2, October 2019, e-ISSN: 2442-482x, p-ISSN: 2089-3345, p.144-162 Copyright@2019 by PJEE 
Indicators:

1. Pay attention to the teacher's explanation

2. Say the name of entities appearing in the 'magic house'

3. Spell the letters several times

4. Find the letters correctly

5. Arrange the letters in the SCREAMBLE board

6. Insert 'grammar function of - s ending' in the letters to indicate quantity

7. Help friends to find the letters

8. Help friends to arrange the letters

Table 4: Result of Wilcoxon Test

Ranks

\begin{tabular}{|c|c|c|c|c|}
\hline & & $\mathrm{N}$ & $\begin{array}{l}\text { Mean } \\
\text { Rank }\end{array}$ & $\begin{array}{c}\text { Sum of } \\
\text { Ranks }\end{array}$ \\
\hline $\begin{array}{l}\text { Posttest - } \\
\text { Pretest }\end{array}$ & $\begin{array}{l}\text { Negative } \\
\text { Ranks } \\
\text { Positive } \\
\text { Ranks } \\
\text { Ties } \\
\text { Total }\end{array}$ & $\begin{array}{c}0^{\mathrm{a}} \\
16^{\mathrm{b}} \\
2^{\mathrm{c}} \\
18\end{array}$ & .00 & $\begin{array}{r}.00 \\
136.00\end{array}$ \\
\hline
\end{tabular}
a. Posttest $<$ Pretest
b. Posttest $>$ Pretest
c. Posttest $=$ Pretest

Test Statistics ${ }^{\mathrm{b}}$

\begin{tabular}{|l|r|}
\hline & Posttest - Pretest \\
\hline Z & -4.000 \\
sAsymp. Sig. (2-tailed) & .000 \\
\hline
\end{tabular}

a. Based o

n negative ranks.

b. Wilcoxon Signed Ranks Test

Interpretation of the tables above was negative ranks between pretest and posttest was 0 both

Premise Journal Vol. 8 No 2, October 2019, e-ISSN: 2442-482x, p-ISSN: 2089-3345, p.144-162

Copyright@2019by PJEE 
in $\mathrm{N}$ and Mean Rank. It represented that there was no decrease between pretest and posttest score. Therefore, positive ranks indicated 16 revealing that 16 preschoolers had a rise in the score between pretest and posttest as 8,50. Besides, there were 2 preschoolers who had got the similar score noticed by ties. Based on the output of Test Statisctics, Asymp.Sig (2-tailed) values 0,000 which was smaller than 0,05 indicates that there was an effectivity of SCREAMBLE media to enhance speaking skill among preschoolers of Kindergarten B at Cahaya Bangsa School.

Figure 2: Magic House and SCREAMBLE board

$$
\text { Magic House SCREAMBLE Board(Testing) SCREAMBLE Board(Final) }
$$
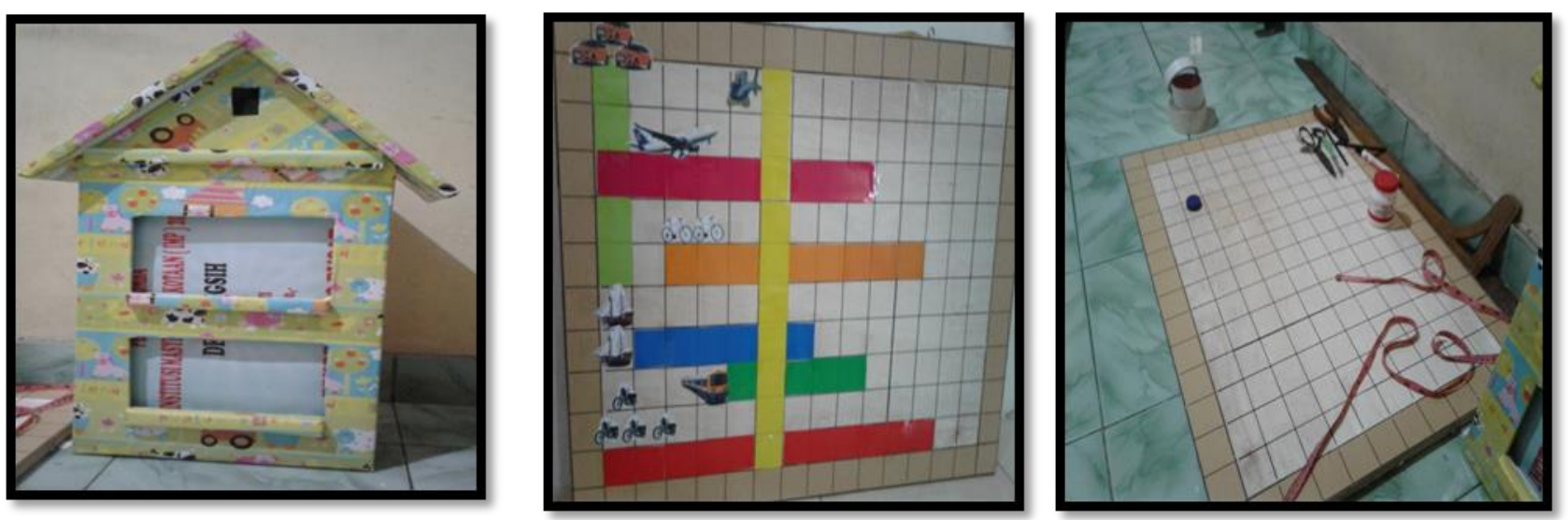

\section{Discussion}

In teaching and learning process, the presence of particular media is somewhat essential to bridge the knowledge and the students. Developing a new media seems better to alter the maxims between modern technology and books. Since speaking asserts performance, it is a little bit difficult to manage what kind of compatible media is. Discovery learning-based assessment module was used to stimulate critical thinking and creativity of students' speaking performance in which the research determined so many types of assessment to promote speaking performance such as conducting group discussion to discuss narrative stories and retelling the story by exchanging some parts of the story based on students' imagination. This assessment module used high order thinking questions to ignite students' critical thinking. So marvelous this finding was since the module reinforce cognitive and psychomotor aspects to 
retell certain occurences which are gained first through reading. For any reasons, reading is not quite appropriate to knock the door between information and brain, specially for preschoolers because it is such a complicated obstacle for non-native english speakers under the age of 6 to read english letters. That is why the researcher tries to discover a new media in the very first level of speaking stages - one word also known as telegraphic speech - to stimulate preschoolers' speaking skill. This media is called SCREAMBLE. Similar to assessment module which involves psychomotor and cognitive aspects of students through reading, SCREAMBLE media accomodates both aspects through spelling and memorizing. Bear in mind that the target learners of SCREAMBLE media are preschoolers who have no underlying concepts of reading and the only one and only way to acquire language is listening.

The other media, audio-based media, that was audio recordings standardized by certain cosiderations as the simplest and easiest application of technology to receive listening process had provided sound input that led students to imitate the audio with accurate pronunciation as one component of fluent speaking. Findings of the research revealed that audio - based media allowed middle school to imitate the audio together which could facilitate the achievement of a learning goal, that was to speak with acceptable pronunciation, stresses and intonation. Similar to the research above, SCREAMBLE media emphasizes the importance of listening as the prominent input to build speaking skill. The difference of audio - based media from SCREAMBLE is that the way to provide accessible input. Audio - based media offered audio whereas SCREAMBLE ensures spelling and memorizing.

This research aimed to develop a media suitable for preschoolers to enhance speaking skill. Since preschoolers do not able to read yet, the presence of spelling and memorizing replaces the function of reading. The last, authentic short movies used to enhance speaking skill seemed to exchange traditional method with something new. The use of movie may have a big impact for students, enable them to get many more vocabularies but preschoolers, tend to be focus only on the picture rather than the vocabularies appear. That is such a challenge for teachers to construct a creative media to extend preschoolers' speaking skill. 
There are certain facts toward preschoolers' difficulty in speaking, those are agerelated factor, languange input and mechanism of acquisition. Most media are developed for middle school since they are able to read, it is such an easy task to get speaking concept. Different from preschoolers whose language input relies only on listening. As some media usually constructed on the shape of module or audio, this research digs up another kind of creative and educative aid namely SCREAMBLE. Bear in mind that the very first cause of speaking difficulty is the lackness of vocabulary. Whereas teachers are the only one facilitators of transferring language input in the school. It may not sufficient enough, that is why the researchers develop another kind of media to enhance speaking which is fit to their ages. This media also accomodates fine motor and cognitive aspects since most children are naturally interested in psychomotor activities.

Learning media that the researcher develops is SCREAMBLE consisting of two components of educative aids named magic house and SCREAMBLE board. Magic house is a media made of recycle carton shaping as manipulative house. It has two front squares function to display flashcards intended. The way to use it is by inserting certain flashcards to spell and memorized alternately by pulling the cards through a long thin hole beside. After memorizing the letters by repeating several times, the preschoolers move to SCREAMBLE board. Early development of SCREAMBLE is giving the starting sign and direction either turn right or get down to ease the preschoolers while arranging letters. In the first testing, the researcher enclosed origami paper cutting into suitable squares as well as pictures of the words to visualize the total of entity for singular or plural things.

Tools of making magic house are; recycled carton, recycled sterofoam, glue, scissors, paper, cutter and flashcards. Firstly, the rsearcher cut the carton into the shape of house 'body'. The researcher made two large squares up and bottom resembling window and door to display flashcards. Next, the researcher cut a long thin hole in right side of the house to pop up the flashcards. The last, the researcher constructed a roof and cover all parts of the house by paper to make preschoolers interested. Whereas the tools of making SCREAMBLE board are recycled board, recycled drinking bottle enclosure and marker. At first, the researcher stucked letters from $\mathrm{A}$ to $\mathrm{Z}$ on the bottle enclosure. One bottle for one letter. Then, the 
researcher drew lines taking after lots of squares so that it could patch words both in turning right and getting down direction.

Furthermore, based on the observation done by the researcher, it can be conluded that there is an enhance in learning process during the use SCREAMBLE media. Preschoolers are better in paying attention to the teachers' explanation because they are interested in magic house and SCREAMBLE board. They are also more excited to spell and memorize the entities appearing in magic house since the researcher conducts such a simple guessing game to trigger them.

Preschoolers seems to be motivated in arranging the letters on SCREAMBLE board identified through their intention to help friends who do not find the letters yet. This way is considered to magnify their affective aspect among the society, in this case, their classmates. The last, the development of SCREAMBLE media has a great impact on preschoolers' comprehension about simple structure and grammar. Grammar thought to them is "-s ending to indicate plural entities' and the result amazingly shows that they are so easy to understand it.

\section{CONCLUSION AND SUGGESTION}

\section{Conclusion}

Some problems faced by preschoolers appear from their stages of development in which they do not able to read yet, so that it has a big impact of their mechanism of acquisition. A media to accomodate this case must be different from media usually used in post-puberty children. Since the source of language input is teachers only, the researcher develop a new media to help preschoolers get better building blocks of speaking through spelling, listening and memorizing. Regarding to the result of this study, SCREAMBLE media

is effective to enhance speaking skill among preschoolers of Kindergarten B at Cahaya Bangsa School.

Through this media, preschoolers can directly apply the letters they have been memorized into the words they arrange themselves. During this process, fine motor of the students is circularly practiced together with logical thinking while rearranging letters. 
SCREAMBLE media is also possible to assert grammar for instance, '-s ending for plural things' so that this media acts flexibly to whole subjects. SCREAMBLE media accustoms speaking skill automatically since they arrange letters and be given feedback soon afterwards in the form of simple question reinforcing them to generate speaking eventhough it is still in the simplest level.

\section{Suggestion}

Based on the development of SCREAMBLE media and its significantly positive influence, in this study, the researcher adresses certain suggestion as follows; (1) it is a must for kindergarten educators to come after development of early childhood education so that there will be a renewal of knowledge, (2) it is better for school to bolster up facilities to sustain the quality of creativity development.

\section{BIO-PROFILE}

Rosita Aryani is an ELT of Early Childhood Education at Cahaya Bangsa School, Metro. She has a great interest in teaching English to Preschoolers. She had just been graduated from IAIN Metro on April 2018, standing her lectures in English Education Department.

\section{REFERENCES}

Fajarwati, H., \&Amirudin,L. (2017). Developing English Learning Material For Speaking Skill Based On Problem -Based Learning (PBI) At First Semester Of The Eighth Grade Of Junior High School. PREMISE JOURNAL:ISSN Online: 2442-482x, ISSN Printed: 2089-3345, 3(2), 50-64. Https://Doi.Org/10.24127/Pj.V3i2.714

Gall, M., Gall, J., \&Borg, W. (2003). Educational Research( $7^{\text {th }}$ Ed). US: Pearson Education, Inc.

Fromkin, V., Rodman,R., \&Hyams, N. (2017). An Introduction to Language (11 ${ }^{\text {th }}$ Ed).US: Cengage Learning, Inc.

Adi, S. S. (2016). The Development Of English Language Learning Instruments Using Audio-Based Media. IOSR Journal Of Research \&Method In Education (IOSR-JRME), 
6(2), 1-12. Https://Doi.Org/10.9790/7388-0602030112

Douglas Brown, H. (2007). Principle Of Language Learning And Teaching.US: Pearson Education, Inc.

Creswell, J. (2014). Research Design: Qualitative, Quantitative and Mixed Method (4 ${ }^{\text {th }}$ Ed). US: SAGE Pub.

Fletcher, P.\& Garman, M. (1986). Language Acquisition ( $2^{\text {nd }}$ Ed). US: Cambridge University Press

Herschensohn, J., Scholten, M. Y. (2013). The Cambridge Handbook of Second Language Acquisition. UK: Cambdrige University Press

Ingram, D. (1998). First Language Acquisition: Method, Description and Explanation. New York: Cambridge University Press

Gass, S. M., \&Selinker, L. (2008). Second Language Acquisition: An Introductory Course( $3^{\text {rd }}$ Ed). New York: Routledge

Harmer, J. (2007). The Practice Of English Language Teaching. US: Longman

Burns, A., Goh, C. M. (2012). Teaching Speaking: A Holistic Approach. UK: Cambridge University Press

O'Grady, W. (2005). How Children Learn Language. UK: Cambridge University Press

Ortega, L. (2009). Understanding Second Language Acquisition. US: Routledge

Yule, G. (2010).The Study of Language ( $4^{\text {th }}$ Ed). UK: Cambridge University Press

Sugiyono, G. (2012). Metode Penelitian Kuantitatif, Kualitatif dan R\&D. Bandung: Alfabeta

Tomlinson, B. (2011). Materials Development in Language Teaching (2 ${ }^{\text {nd }}$ Ed). UK: Cambridge University Press

Krashen, S. D., Mack, C., Momenah, R., \&Wagner, E. (2016). Assessment Tools \&Strategies Language Proficiency Assessment. In The Modern Language Journal(Vol. 15).

Macwhinney, B. (2015). Language Acquisition. International Encyclopedia Of The Social \&Behavioral Sciences: Second Edition, 245-250. Https://Doi.Org/10.1016/B978-0-08097086-8.54011-2

Madiyoh, R., Hidayanto, N., \&Setyo, P. (2018). The Effectiveness Of Authentic Short Movies In Enhancing Students Speaking Skill. 6(June), 44-49. Https://Doi.Org/10.14662/IJELC2018.030

Mayo, M. D. P. G., \&Soler, E. A. (2013). Negociated Input And Output Interaction. In The Cambridge Handbook Of Second Language Acquisition.

Premise Journal Vol. 8 No 2, October 2019, e-ISSN: 2442-482x, p-ISSN: 2089-3345, p.144-162

Copyright@2019 by PJEE 
Mede, E., Cosgun, G., \&Atay, D. (2017). The Use Of Speaking Techniques By Native And Non-Native English Instructors: A Case In Turkey. International Journal Of Learning And Teaching, 9(4), 411-417. Https://Doi.Org/10.18844/Ij1t.V9i4.2646

Milaningrum, E., \&Rahmawaty, P. (2019). Developing English Module For Hospitality Students Using Inquiry-Based Language Learning In Balikpapan State Polytechnic. Premise: Journal Of English Education, 8(1), 1. https://Doi.Org/10.24127/Pj.V8i1.1928

Qomar, A. H., \& Erlina, I. A. H. (2017). DEVELOPING MATERIAL FOR COMMUNICATIVE LANGUAGE TEACHING (CLT) TO TEACH ENGLISH FOR ECONOMICS STUDENTS. Premise: Journal of English Education, 6(2), 12-19.

Turmudi, D., \& Baihaqi, Y. (2019). DEVELOPING AN ENGLISH ESSAY MATERIALS FOR UNIVERSITY STUDENTS. In Listiyani, \& E. T. Murtisari (Ed.), The 11th FLA IINTERNATIONAL CONFERENCE PROCEEDINGS (pp. 17-30). Salatiga, Indonesia: Satya Wacana University Press. Retrieved from https://scholar.google.com/citations?user=MeLCNqgAAAAJ\&hl=en\&gmla=AJsNF6MBQCmIhQhpmyvBwOFiNGia6g435pcGR7rb_gwVA3hz8Rru7IcnuTzccEzQ049CUdIetXEZ9AMFVpg1hprFtg5eDyEwkk0OhK62_3YdyG Cm47hHM\&sciund $=14347828958573310550$

Wahyudi, R., Rukmini, D., Anggani, D., \&Bharati, L. (2019). English Education Journal Developing Discovery Learning-Based Assessment Module To Stimulate Critical Thinking And Creativity Of Students' Speaking Performance. Eej, 9(2), 2019-2172. Retrieved From Http://Journal.unnes.ac.id/Sju/Index.Php/Eej

Yuniarti (2017). Developing Speaking Materials Based On The Common European Framework Of Reference (CEFR) For Increasing The Students' Speaking Skill. Pedagogy : Journal Of English Language Teaching, [S.L.], 4(2)143-156. ISSN 2580-1473. Http://Dx.Doi.Org/10.2332/Pedagogy.Vi2.384

Premise Journal Vol. 8 No 2, October 2019, e-ISSN: 2442-482x, p-ISSN: 2089-3345, p.144-162 Copyright@2019 by PJEE 